\title{
青藏高原两种高寒草地植被变化及其水温驱动因素 分析
}

\author{
梁大林, 唐海萍* \\ 北京师范大学地理科学学部自然资源学院, 北京 100875
}

\begin{abstract}
摘要: 高寒草甸和高寒草原作为青藏高原两种重要植被类型, 研究其植被变化与气候变化相关性, 有助于为青藏高原两种高寒 草地生态系统应对全球气候变化管理提供参考。以位于同纬度的三江源高寒草甸和阿里高寒草原为研究对象, 基于植被净初 级生产力 (Net Primary Productivity, NPP) 变化表征植被变化, 利用 NPP 数据和气象数据, 分别分析两地 2000一-2017 年植被 NPP、降水和气温时空变化差异; 利用 Sen+ Mann-Kendall 趋势检验, 研究两种高寒草地气候与植被净初级生产力变化趋势; 以 县域统计年鉴牛羊肉产量表征放牧强度, 研究放牧活动对高寒草地植被变化的影响; 通过 Pearson 相关和偏相关分析方法, 分别 研究降水和气温对两种高寒草地植被 NPP 变化影响差异。研究结果表明: (1) 2000-2017 年三江源高寒草甸和阿里高寒草原 区年平均气温以 $0.085^{\circ} \mathrm{C} / \mathrm{a}$ 和 $0.084^{\circ} \mathrm{C} / \mathrm{a}$ 的趋势上升, 降水以平均每年 $3.87 \mathrm{~mm}$ 和 $2.23 \mathrm{~mm}$ 的趋势增加, 高寒草甸区变暖变湿速 率较高寒草原区快。(2) 三江源高寒草甸和阿里高寒草原植被 NPP 均呈现由东南向西北逐渐降低空间格局; 2000-2017 年高 寒草甸区 $57.7 \%$ 植被 NPP 呈现上升趋势, 而高寒草原区 $50.96 \%$ 植被 NPP 呈现上升趋势, 高寒草甸植被 NPP 增长趋势较高寒草 原明显。(3) 三江源高寒草甸和阿里高寒草原两种草地植被变化受放牧影响不大, 受气候变化影响较大。(4) 三江源高寒草甸 大部分植被 NPP 增长与气温呈显著正相关而与降水呈显著负相关, 高寒草甸植被 NPP 主要受温度调控, 而阿里高寒草原植被 NPP 受降水和温度的双重调控。
\end{abstract}

关键词:净初级生产力;气象因子;相关性;高寒草甸;高寒草原

\section{Analysis of vegetation changes and water temperature driving factors in two alpine grasslands on the Qinghai-Tibet Plateau}

\author{
LIANG Dalin, TANG Haiping* \\ School of Natural Resources, Faculty of Geographical Science, Beijing Normal University, Beijing 100875, China
}

\begin{abstract}
Alpine meadow and alpine steppe are two important vegetation types on the Qinghai-Tibet Plateau. Studying the correlation between vegetation change and climate change in alpine meadow and alpine steppe is helpful to provide reference for the management of the two alpine grassland ecosystems on the Qinghai-Tibet Plateau in response to global climate change. In this study, the alpine meadow of the Three-River Headwaters Region and the alpine steppe of Ali located in the same latitude were taken as the research objects. Vegetation changes were characterized based on the changes of Net Primary Productivity ( NPP) of vegetation. Based on NPP data and meteorological data, the spatial and temporal variations of NPP, precipitation and air temperature between 2000 and 2017 were analyzed. Sen+ Mann-Kendall trend test was used to study the change trend of climate and vegetation net primary productivity in two alpine grasslands. The effects of grazing activities on the vegetation change of alpine grassland were studied by using the yield of beef and mutton in county statistical
\end{abstract}

基金项目:第二次青藏高原综合科学考察研究(2019QZKK0606)

收稿日期: 2020-12-03; 网络出版日期:2021-08- 16

* 通讯作者 Corresponding author.E-mail: tanghp@ bnu.edu.cn 
yearbooks. Through Pearson correlation and partial correlation analysis, the variation trend of precipitation and air temperature on vegetation NPP and the difference of precipitation and air temperature on NPP of two alpine grasslands were studied respectively. The results show that: (1) from 2000 to 2017, the annual average temperature in Three-River Headwaters Region alpine meadow and Ali alpine steppe increased at $0.085^{\circ} \mathrm{C} / \mathrm{a}$ and $0.084^{\circ} \mathrm{C} / \mathrm{a}$, and the annual average precipitation increased at $3.87 \mathrm{~mm}$ and $2.23 \mathrm{~mm}$, respectively. The warming and wetness rate in the alpine meadow was faster than that in the alpine steppe. (2) The NPP of the alpine meadow in the Three-River Headwaters Region and the alpine steppe in Ali showed a decreasing spatial pattern from southeast to northwest. From 2000 to 2017, the NPP of 57.7\% of alpine meadow vegetation presented an upward trend, while that of $50.96 \%$ of alpine steppe vegetation showed an upward trend. The NPP of alpine meadow vegetation increased more obviously than that of alpine steppe. (3) The alpine meadow in the Three-River Headwaters Region and the alpine steppe in Ali region were less affected by grazing and more affected by climate change. (4) The NPP growth of most alpine meadow vegetation in the Three-River Headwaters Region was significantly positively correlated with air temperature and negatively correlated with precipitation. The NPP of alpine meadow vegetation was mainly regulated by temperature, while the NPP of alpine steppe vegetation in the Ali region was controlled by both precipitation and temperature.

Key Words : net primary productivity; meteorological factors; correlation; alpine meadow ; alpine steppe

青藏高原草地资源占全国总草地资源的 $1 / 3$, 是我国面积最大的天然草地 ${ }^{[1-2]}$, 研究青藏高原不同草地 植被变化对草地资源保护与调查具有重要意义。青藏高原也是我国重要的生态功能区, 是全球气候变化最敏 感的地区之一 ${ }^{[3-4]}$, 其草地植被对气候变化响应研究一直是众多学者关注的焦点问题之一 ${ }^{[5-9]}$ 。

上世纪以来青藏高原地区年平均气温总体呈现出升高的趋势, 年降水量在近 40 年呈现增加趋势 ${ }^{[10]}$, 这 种以变暖变湿为主要特征的气候变化对青藏高原植被覆盖具有重要影响, 高寒草地作为青藏高原主要植被类 型之一,受气候变化影响较为显著 ${ }^{[11-12]}$ 。植被 NPP 是衡量植物在自然环境条件下的生产能力, 表征全球变 化对陆地生态系统影响及相应关键参数 ${ }^{[13-14]}$, 不少学者基于植被 NPP 研究植被变化 ${ }^{[15-17]}$, 从时空尺度探讨 植被 NPP 变化特征及其与气候变化之间的关系 ${ }^{[18]}$ 。张镱锂等 ${ }^{[19]}$ 利用 CASA 模型估算青藏高原高寒草地 1982-2009 年间植被净初级生产力, 分析了高寒草地植被 NPP 时空格局与变化特征, 对青藏高原草地植被 NPP 变化有整体认识; Zheng 等 ${ }^{[20]}$ 研究青藏高原 2001-2015 年植被 NPP 时空格局及其对气温、降水和太阳 辐射的响应, 从总体上对青藏高原植被 NPP 与气候因素进行分析; 韩炳宏等 ${ }^{[21]}$ 通过植被 NDVI 研究了青藏高 原 2000-2018 年植被覆盖变化及其与气候因素的关系, 得出青藏高原植被整体呈稳定恢复状态, 与降水和温 度呈正相关。前人在青藏高原植被 NPP 变化方面做了很多研究, 取得众多研究成果, 但对青藏高原不同地区 具体植被类型 NPP 变化与气候变化响应差异研究相对欠缺。周秉荣等 ${ }^{[22]}$ 研究发现三江源区近 54 年植被 NPP 整体呈显著增加趋势, 气温是影响该地区植被 NPP 增加的主要气象因素, 该研究只是针对三江源植被, 气温是否也是影响青藏高原其他地区植被 NPP 增加的主要气象因素需进一步研究; 陈舒婷等 ${ }^{[23}$ 通过相关分 析和重心模型等方法对 2000-2015 年整个青藏高原植被 NPP 时空变化格局及其驱动机理进行研究, 从整体 上区分气候变化和人类活动对植被变化的影响。而戴黎聪等 ${ }^{[24]}$ 只是分析了青藏高原高寒小嵩草草甸和高寒 金露梅灌丛两种植被 NPP 变化和气候相关性, 对全球变暖背景下这两种植被 NPP 变化差异有进一步认识, 而对于高寒草甸和高寒灌丛是否也成立, 需要进一步研究。

现有研究主要集中在青藏高原整体植被 NPP 时空分布格局及其对气候响应, 为青藏高原区域尺度上长 时间序列植被 NPP 时空分异格局与变化规律研究奠定了基础 ${ }^{[25]}$, 但对青藏高原内部不同区域、不同草地类型 之间植被 NPP 与气候变化相关性差异研究较少, 缺乏对青藏高原不同草地植被生长与气候制约因子比较研究。 而高寒草甸和高寒草原作为青藏高原两种典型植被类型, 是青藏高原高寒草地生态系统的主体 ${ }^{[26-27]}$, 在不同地 区、不同气候环境下,二者对气候变化的响应也可能存在显著差异,目前关于两者对比研究相对欠缺。 
基于此,本文以三江源高寒草甸和阿里高寒草原为研究对象,利用研究区 2000-2017 年草地植被月最大 值 NPP 变化表征植被变化(下文所提 NPP 均代表月最大值 NPP), 根据气象站点数据插值得到研究区气温、 降水时空变化, 研究两种高寒草地植被变化与气象因子相关性,得出气象因子对两种高寒草地植被变化影响 差异,为青藏高原不同草地植被对气候变化响应研究提供参考。

\section{1 研究区与研究方法}

1.1 研究区概况

三江源地区位于我国青海省南部 (图 1), 是长江、黄河和澜沧江的发源地, 平均海拔 $3500-4800 \mathrm{~m}$ 。该区 域总面积达 $38.24 \times 10^{4} \mathrm{~km}^{2}$, 年平均气温低于 $-1{ }^{\circ} \mathrm{C}$, 属于典型的高原大陆性气候, 冷热两季交替、干湿季节分 明,且植被类型以高寒草甸为主 ${ }^{[28]}$ 。

阿里地区位于青藏高原北部西藏自治区西部(图 1), 平均海拔 $4500 \mathrm{~m}$ 以上, 素有“世界屋脊” 的屋脊之 称。该地区总面积约为 $33.7 \times 10^{4} \mathrm{~km}^{2}$, 年平均气温在 $0.4-3.6^{\circ} \mathrm{C}$ 之间, 属亚寒带干旱高原气候区, 植被类型以 高寒草原为主 ${ }^{[29-30]}$ 。

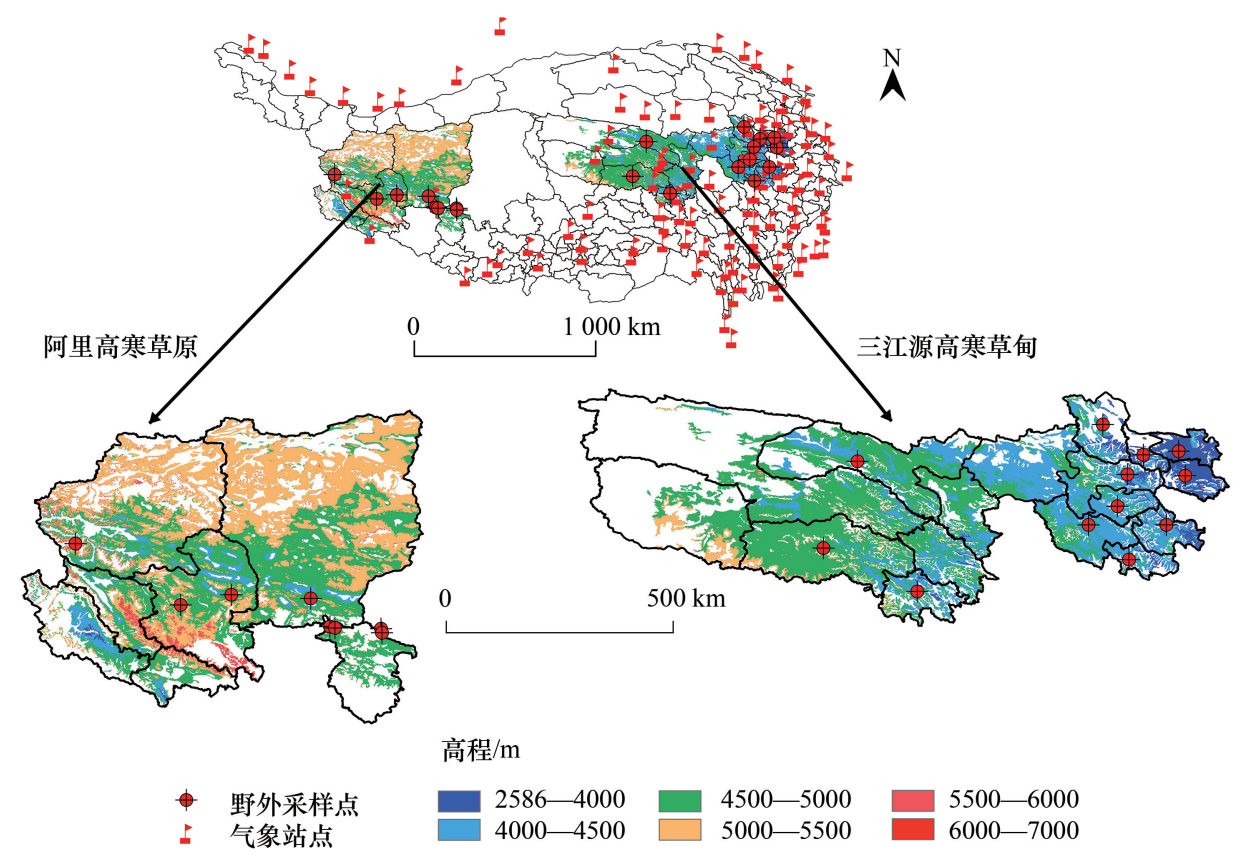

图 1 研究区采样点、气象站点和高程分布

Fig.1 Sampling points, meteorological stations and elevation distribution in the study area

1.2 数据来源与预处理

本研究所采用数据和预处理过程如下

(1) 研究区草地类型数据源自 1:100 万植被图 (图 1)。(2) 2000 年 3 月一-2018 年 2 月降水、气温月值数 据集均来自国家气象科学数据中心 (http://www. nmic.cn/), 包括青藏高原及周边地区 102 个气象站点 (图 1); 利用专业气象插值软件 ANUSPLIN 对各年月值气象数据插值, 得到青藏高原 2000-2017 年 $250 \mathrm{~m}$ 分 辨率气温与降水栅格数据。ANUSPLIN 插值是一种广泛应用于青藏高原气候因子模拟的方法, 插值时加人高 程协变量能较好地拟合青藏高原气象要素 ${ }^{[7]} 。(3)$ 三江源与阿里地区各县牛羊肉产量数据来源于中国知网 中青海省统计年鉴(https://www.cnki.net/)。(4) NPP 数据来源于国家青藏高原科学数据中心 ( https://data. tpdc.ac.cn/zh-hans/) 青藏高原生态资产评估遥感反演净初级生产力数据集 ${ }^{[31-32]}$, 空间分辨率 $250 \mathrm{~m} \times 250 \mathrm{~m}$ 。 本研究最后将所有数据重采样为 $250 \mathrm{~m} \times 250 \mathrm{~m}$ 栅格数据。 


\subsection{NPP 数据评估}

本研究分析所用 NPP 数据均来自青藏高原生态资产评估遥感反演净初级生产力数据集, 时间跨度 2000-2017 年,该数据集基于 CASA 模型计算得到植被月最大值 $\mathrm{NPP}^{[31]}$, 代表植被一年中生长最好月份状 况。为评估实验数据在三江源与阿里地区的可靠性, 本研究基于 Liang 等人 ${ }^{[33]}$ 发表文献中实测生物量数据评 估三江源区数据准确性, 利用国家青藏高原科学数据中心公开的藏北样带实测生物量数据评估阿里区数据准 确性。通过对研究区 NPP 数据与实测生物量数据进行相关与线性回归分析, 结果表明, 三江源区高寒草甸植 被 NPP 与实测生物量数据相关系数达 $0.863(P<0.001)$, 线性回归拟合优度 $R^{2}$ 为 0.749 ; 阿里地区高寒草原 $\mathrm{NPP}$ 与实测生物量数据相关系数达 $0.833(P<0.05)$, 线性回归拟合优度 $R^{2}$ 为 0.695 (图 2)。由此可见, 本研究 所用产品中两种高寒草地植被 NPP 计算结果可靠, 可进行下步相关研究。

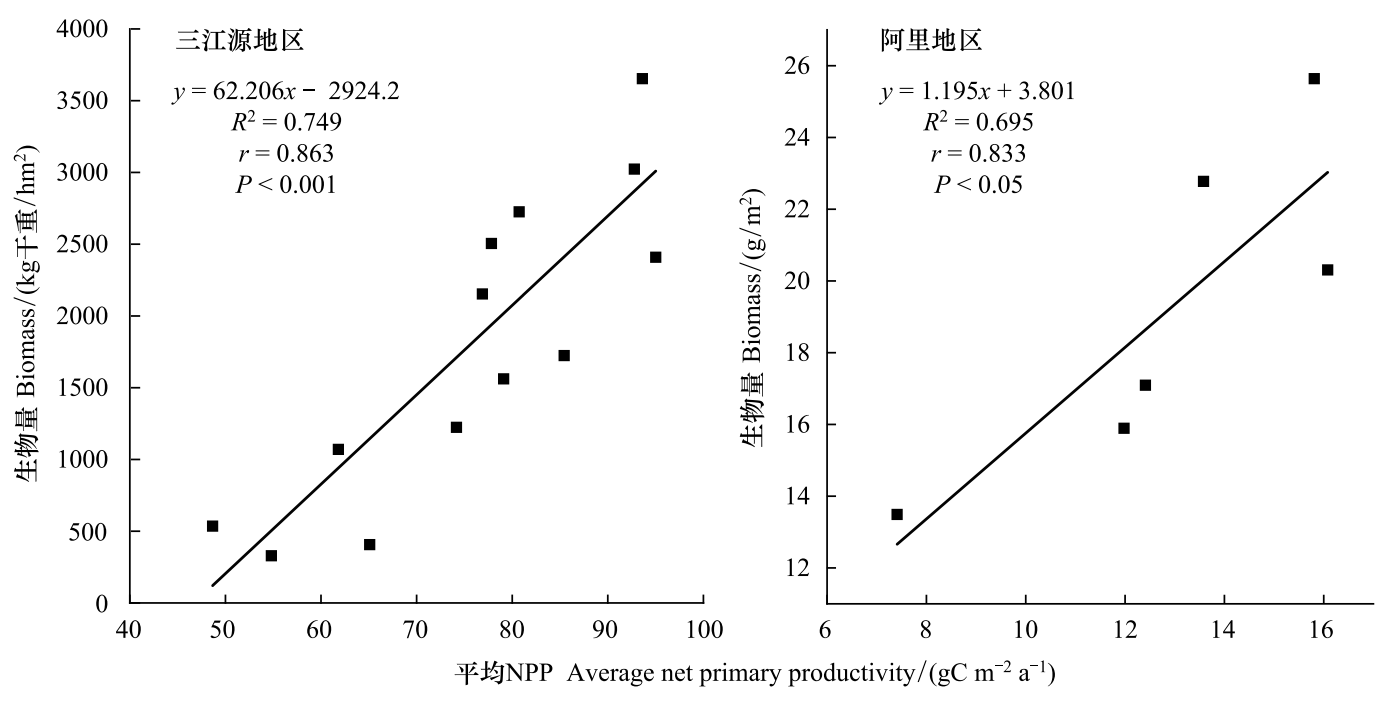

图 2 研究区 NPP 数据与实测生物量数据线性拟合

Fig.2 Linear fit between NPP data and measured biomass data in the study area

\section{4 研究方法}

\subsubsection{Sen+M-K 趋势分析}

对 NPP 及气象数据趋势分析一般采用回归分析或 Mann-Kendall (M-K) 趋势分析, 回归分析要求时间序 列符合正态分布, 且结果容易受噪声干扰 ${ }^{[34]}$ 。相比之下 Theil-Sen Median (Sen) 趋势度分析是计算序列中的 中位数, 可以很好地减少噪声干扰, 是一种稳健的非参数统计的趋势计算方法, 但其本身不能实现序列趋势显 著性判断。这两种方法结合使用在时间序列趋势分析中具有很大优势, 不仅可以有效增强抗噪性, 且更准确 地检验时间序列趋势及其显著性。本文利用 Sen 趋势度对时间序列趋势进行判断, 利用 M-K 趋势检验法对 趋势显著性进行检验。

Sen 趋势计算公式:

$$
\text { Sen }=\operatorname{Median}\left(\frac{x_{j}-x_{i}}{j-i}\right), \forall j>i
$$

式中, $x_{j}$ 和 $x_{i}$ 为时间序列数据, Median ( ) 表示序列中位数, 当 $\operatorname{Sen}>0$ 表示时间序列呈现上升趋势; 当 Sen $<0$ 表 示时间序列呈下降趋势 ${ }^{[35]}$ 。

M-K 趋势显著性检验方法如下:

$$
\operatorname{sgn}\left(x_{j}-x_{i}\right)=\left\{\begin{array}{c}
+1, x_{j}-x_{i}>0 \\
0, x_{j}-x_{i}=0 \\
-1, x_{j}-x_{i}<0
\end{array}\right.
$$




$$
S=\sum_{i=1}^{n-1} \sum_{j=i+1}^{n} \operatorname{sgn}\left(x_{j}-x_{i}\right)
$$

式中, $x_{j}$ 和 $x_{i}$ 为时间序列数据, $n$ 为数据个数; 当 $n \geqslant 8$ 时, (3) 式检验统计量 $S$ 近似为正态分布。

根据统计量 $\mathrm{S}$ 标准化检验统计量 $Z$ :

$$
Z=\left\{\begin{array}{l}
\frac{S}{\sqrt{\operatorname{Var}(S)}}(S>0) \\
0(S=0) \\
\frac{S+1}{\sqrt{\operatorname{Var}(S)}}(S<0)
\end{array}\right.
$$

原假设 $H_{0}$ 表示时间序列 $\left(x_{1} 、 x_{2} 、 x_{3} 、 \cdots, x_{n}\right)$ 是独立同分布样本数据, 不存在时间序列趋势, 备择假设 $H_{1}$ 表示序列存在上升或下降趋势。在给定显著性水平 $\alpha$ 下, 若 $|Z| \geqslant Z_{1-\alpha / 2}$, 则拒绝原假设 $H_{0}$, 在置信水平 $\alpha$ 上采用备择假设, 即时间序列数据存在显著上升或下降趋势。在本文检验中 Sen $>0$ 表示呈上升趋势, Sen $<0$ 表示下降趋势; 当 $Z$ 的绝对值大于 $1.65 、 1.96$ 和 2.58 时,表示趋势通过的信度分别为 $90 \% 、 95 \%$ 和 $99 \%$ 的显著 性检验。

M-K 方法还可以用于突变检验, 假定有 $n$ 个样本的时间序列 $x_{1}, x_{2}, \cdots, x_{n}$, 构造一秩序列:

$$
S_{m}=\sum_{i=1}^{m} r_{i} \quad(m=2,3, \cdots, n)
$$

式中, $x_{i}>x_{j}$ 时, $r_{i}=+1 ; x_{i}<x_{j}$ 时, $r_{i}=0(j=1,2, \cdots, i)$, 在时间序列随机独立的假定下, 定义统计量为

$$
U F_{m}=\frac{\left[S_{m}-\overline{S_{m}}\right]}{\sqrt{\operatorname{Var}\left(S_{m}\right)}} \quad(m=1,2, \cdots, n)
$$

式中, $m=1$ 时, $U F_{1}=0, \operatorname{Var}\left(S_{m}\right) 、 \overline{S_{m}}$ 是累计量 $S_{m}$ 的方差和均值, $\operatorname{Var}\left(S_{m}\right) 、 \overline{S_{m}}$ 计算公式见文献 $[35], U F_{i}$ 为 标准正态分布, 由时间序列 $x_{1}, x_{2}, \cdots, x_{n}$ 计算得出的统计量, 在给定显著性水平 $\alpha,\left|U F_{i}\right|>U F_{\alpha / 2}$, 表明序列 有明显的变化趋势, 按时间逆序 $x_{n}, \cdots, x_{2}, x_{1}$, 再重复上述过程, 使 $U F_{m}=-U B_{m}(k=n, n-1, \cdots, 1), U B_{1}=0$, 当 $U F_{m}$ 或 $U B_{m}$ 大于 0 , 表示序列上升趋势, 小于 0 表明呈下降趋势。本研究取 $\alpha=0.05, U F_{\alpha / 2}=1.96,\left|U F_{i}\right|>$ 1.96 时, 表示序列呈显著变化趋势 ${ }^{[35]}$ 。

1.4.2 相关与偏相关性计算

本文对阿里和三江源地区草地 NPP 与气象因子分别采用逐像元相关与偏相关分析。由于年降水量和年 平均温度都对草地 NPP 有影响, 控制其中一种气象要素不变, 研究另一种气象要素对草地 NPP 的影响 ${ }^{[36]}$, 计 算原理见参考文献 $[36]$ 。

Pearson 相关分析计算公式如下式(7)：

偏相关分析计算公式如下式(8)

$$
r_{x y}=\frac{\sum_{k=1}^{n}\left(x_{k}-\bar{x}\right)\left(y_{k}-\bar{y}\right)}{\sqrt{\sum_{k=1}^{n}\left(x_{k}-\bar{x}\right)^{2} \sum_{k=1}^{n}\left(y_{k}-\bar{y}\right)^{2}}}
$$

$$
r_{x y \cdot z}=\frac{r_{x y}-r_{x z} r_{y z}}{\sqrt{\left(1-r_{x z}{ }^{2}\right)\left(1-r_{y z}{ }^{2}\right)}}
$$

式中, $n$ 表示时间序列长度,本研究时间序列为 $18, r_{x y}$ 表示 $x$ 与 $y$ 之间相关系数, $r_{x y \cdot z}$ 表示控制变量为 $z$ 时, $x$ 与 $y$ 之间偏相关系数 ${ }^{[37]}$ 。

本研究数据处理使用了 ANUSPLIN 和 Matlab 软件, 结果分析与统计地图制作使用了 Origin 和 ArcMap 软件。 


\section{2 结果与分析}

2.1 三江源与阿里地区气温与降水变化

通过对气象站点进行 ANUSPLINE 气象插值得到三江源地区与阿里地区 2000-2017 年气温与降水栅格 数据, 并对数据进行趋势分析。计算结果表明三江源地区与阿里地区年平均气温总体均呈现上升趋势, 但二 者年际升温幅度差异较大。阿里地区从 2000 年的 $2.59^{\circ} \mathrm{C}$ 上升至 2017 年的 $4.12^{\circ} \mathrm{C}$, 平均年际增长为 $0.085^{\circ} \mathrm{C} /$ $\mathrm{a}$ ( 图 3、图 4), 而三江源地区升温相对不稳定, 三江源地区年际平均气温变化大, 在 2000-2013 年间, 气温上 下波动较大,从 2014 年开始呈现明显上升趋势, 2000-2017 年平均增长速率为 $0.084^{\circ} \mathrm{C} / \mathrm{a}$ 。阿里地区年平均 气温 M-K 趋势分析表明,2000-2017 年气温均为上升趋势, 其中 2007 年、2012 年和 2017 年上升趋势显著 (图 4)。即 2000-2017 年阿里地区年平均气温相对稳步上升, 而三江源地区 2000-2014 年气温波动较大, $2014-2017$ 年气温上升显著。

在降水方面,三江源地区与阿里地区年降水量均呈现不同程度的上升趋势。三江源地区年降水量从 2000 年 $363.84 \mathrm{~mm}$ 上升至 2017 年的 $433.61 \mathrm{~mm}$; 而阿里地区年降水量从 2000 年的 $163.93 \mathrm{~mm}$ 上升至 2017 年 的 $204.12 \mathrm{~mm}$, 两地降水均呈现不同程度波动增长。降水 M-K 趋势分析表明, 2008-2014 年三江源地区降水 呈显著上升趋势 $(\alpha<0.05)$, 阿里地区降水上升趋势不显著 $(\alpha>0.05)$ 。

三江源地区
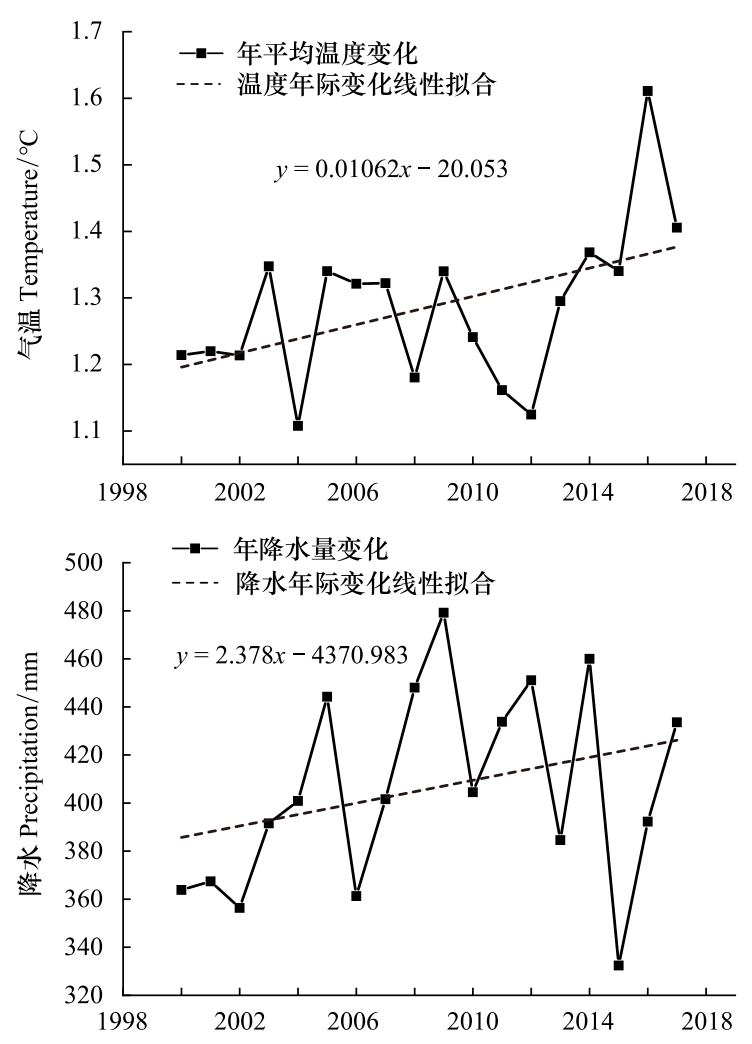

阿里地区
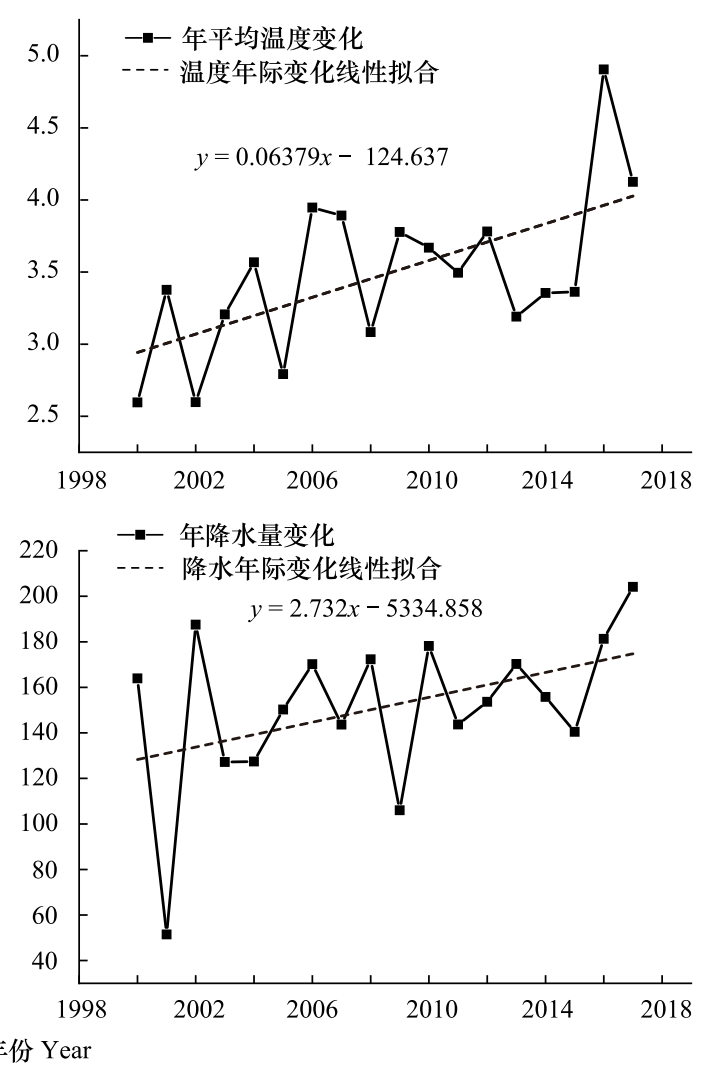

图 3 研究区年平均气温与累计年降水变化

Fig.3 Annual average temperature and cumulative annual precipitation changes in the study area

\section{2 研究区两种高寒草地植被变化时间对比分析}

从 2000 年到 2017 年, 三江源和阿里地区高寒草地植被平均 NPP 均呈现轻微上升趋势, 其中三江源地区 高寒草甸植被 NPP 平均年增长率为 $0.49 \mathrm{gC} \mathrm{m}^{-2} \mathrm{a}^{-1}$, 阿里地区高寒草原植被 NPP 平均年增长率为 $0.0454 \mathrm{gC}$ 


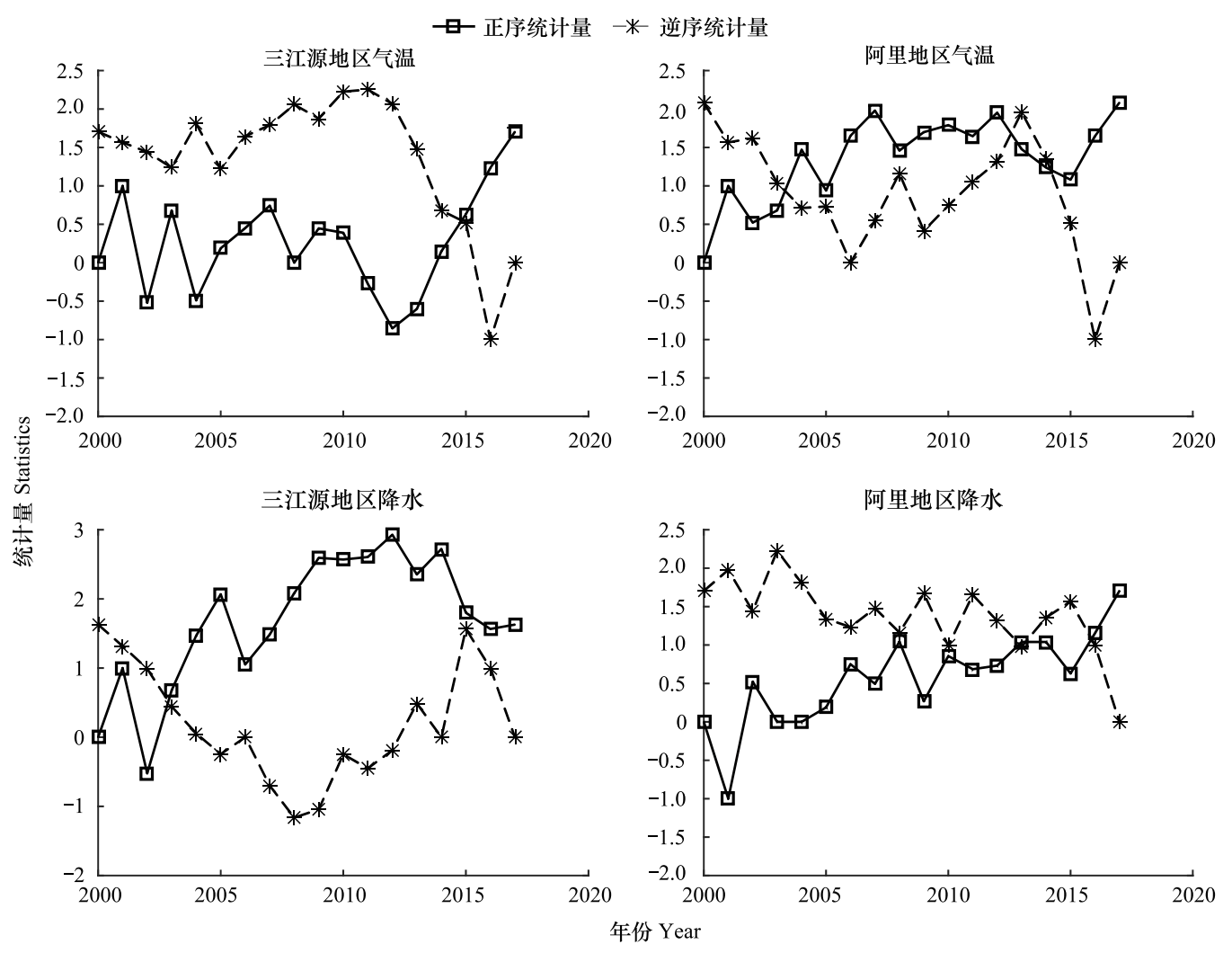

图 4 研究区年平均气温与累计年降水变化趋势 M-K 突变性检验

Fig.4 M-K mutation test of the variation trend of annual average temperature and cumulative annual precipitation in the study area $U F$ : 正序统计量 Positive sequence statistics; $U B$ : 逆序统计量 Inverse sequence statistics

$\mathrm{m}^{-2} \mathrm{a}^{-1}$ (图 5)。分时间段看,两种高寒草地植被 NPP 变化具有一定差异,三江源地区 2000-2005 年高寒草甸 植被 NPP 出现轻微下降趋势;而阿里地区 2000-2005 年高寒草原植被 NPP 出现轻微上升趋势。从 2007 年 到 2017 年,三江源地区高寒草甸植被 NPP 出现明显波动上升趋势, 而阿里地区高寒草原植被 NPP 在 2010一 2017 年呈现增长趋势。
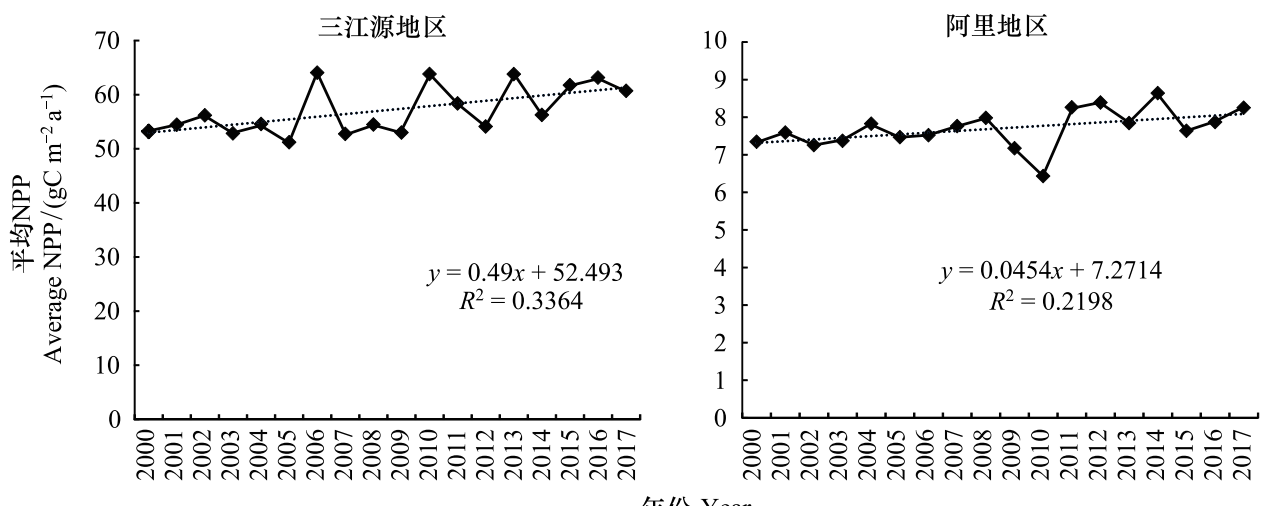

年份 Year

图 5 两种高寒草地植被 NPP 年际变化

Fig.5 Interannual changes in NPP of vegetation in two types of alpine grasslands

2.3 研究区两种高寒草地 NPP 空间分布及变化趋势

空间上两种高寒草地植被 NPP 均呈现由东南向西北逐渐递减格局 (图 6); 阿里地区高寒草原 NPP 整体 
处于相对较低水平,月最大值 NPP 不超过 $30 \mathrm{gC} \mathrm{m}^{-2} \mathrm{a}^{-1}, \mathrm{NPP}$ 相对高值区集中在普兰县、措勤县和改则县南 部, 而日土县及改则县西北部地区,高寒草原 NPP 均处于最低值。三江源地区高寒草甸 NPP 整体比阿里地 区高寒草原高,空间上高值区分布也相对更集中。如三江源地区 NPP 高值集中分布东北部库泽县和河南蒙 古自治县以及玉树县和囊谦县连片区 $92.7-139.1 \mathrm{gC} \mathrm{m}^{-2} \mathrm{a}^{-1}$, 在玛多县和称多县地区 NPP 值处于中间水平, 而格尔木市及治多县西北部 NPP 最低 $0-26.2 \mathrm{gC} \mathrm{m}^{-2} \mathrm{a}^{-1}$; 相比阿里地区, 三江源地区高寒草原 NPP 低值集中 分布在北部及西部边缘地区。

研究区两种高寒草地 2000-2017 年 NPP 变化趋势差异明显(图 7 和表 1), 高寒草甸 NPP 增长趋势较高 寒草原明显。高寒草甸 NPP 呈上升趋势部分占总面积 $57.7 \%$,下降趋势占总面积 $42.3 \%$, 其中呈显著上升趋 势占比 $13 \%$, 显著下降趋势占比 $6.49 \%$, 高寒草甸 NPP 总体呈上升趋势。而高寒草原 NPP 上升趋势略比下降 趋势占比高, 上升趋势占比 $50.96 \%$,下降趋势占比 $49.04 \%$, 总体 NPP 上升部分相对较少。空间上, 位于三江 源地区的高寒草甸 NPP 增长区主要集中在西南部的格尔木市、杂多县和治多县, 这些地区均为气温和降水相 对较低区域。阿里地区高寒草原 NPP 增长区主要集中在改则县和日土县北部及札达县, 其中改则县北部上 升趋势最显著。通过对比发现, 三江源与阿里地区高寒草地 NPP 增长显著区均位于降水和温度相对低值 区域。
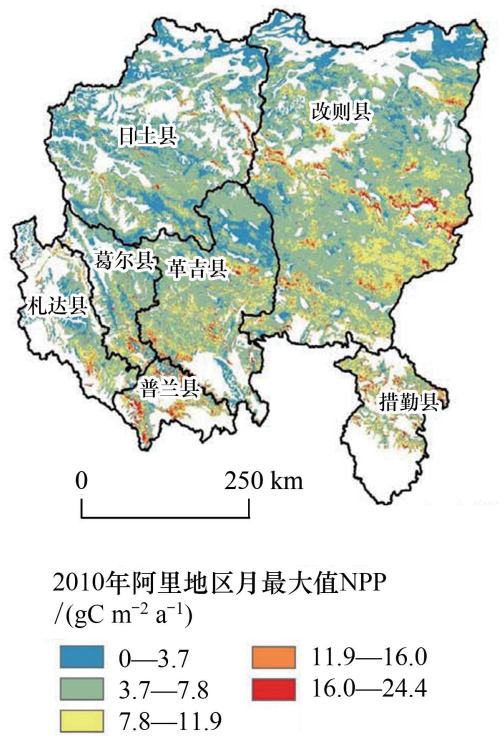
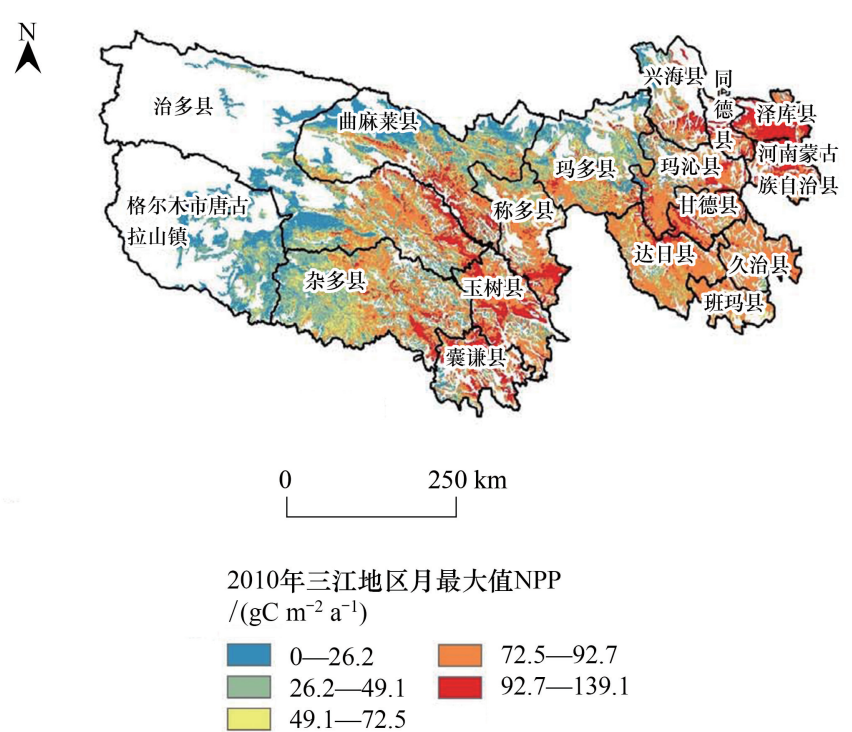

图 6 研究区 NPP 空间分布

Fig.6 Patial distribution of NPP in the study area

表 1 两种高寒草地 NPP 变化趋势 M-K 检验统计

Table 1 M-K test statistics of NPP trend of two typical grassland

\begin{tabular}{lccc}
\hline $\begin{array}{l}\text { 草地类型 } \\
\text { Grass type }\end{array}$ & $\begin{array}{c}\text { NPP 变化趋势 } \\
\text { NPP change trend }\end{array}$ & $\begin{array}{c}\text { 栅格数 } \\
\text { Number of grids }\end{array}$ & $\%$ \\
\hline 高寒草甸(三江源地区) & Sen>0, $|Z|>1.65$ & 397046 & 13 \\
Alpine meadow (TRHR) & Sen>0, $|Z|<1.65$ & 1365084 & 44.7 \\
& Sen<0, $|Z|>1.65$ & 198220 & 6.49 \\
& Sen<0, $|Z|<1.65$ & 1093517 & 35.81 \\
高寒草原(阿里地区) & Sen>0, $|Z|>1.65$ & 450892 & 12.62 \\
Alpine steppe (Ali area) & Sen>0, $|Z|<1.65$ & 1370021 & 38.34 \\
& Sen<0, $|Z|>1.65$ & 356470 & 9.98 \\
\hline
\end{tabular}


三江源地区
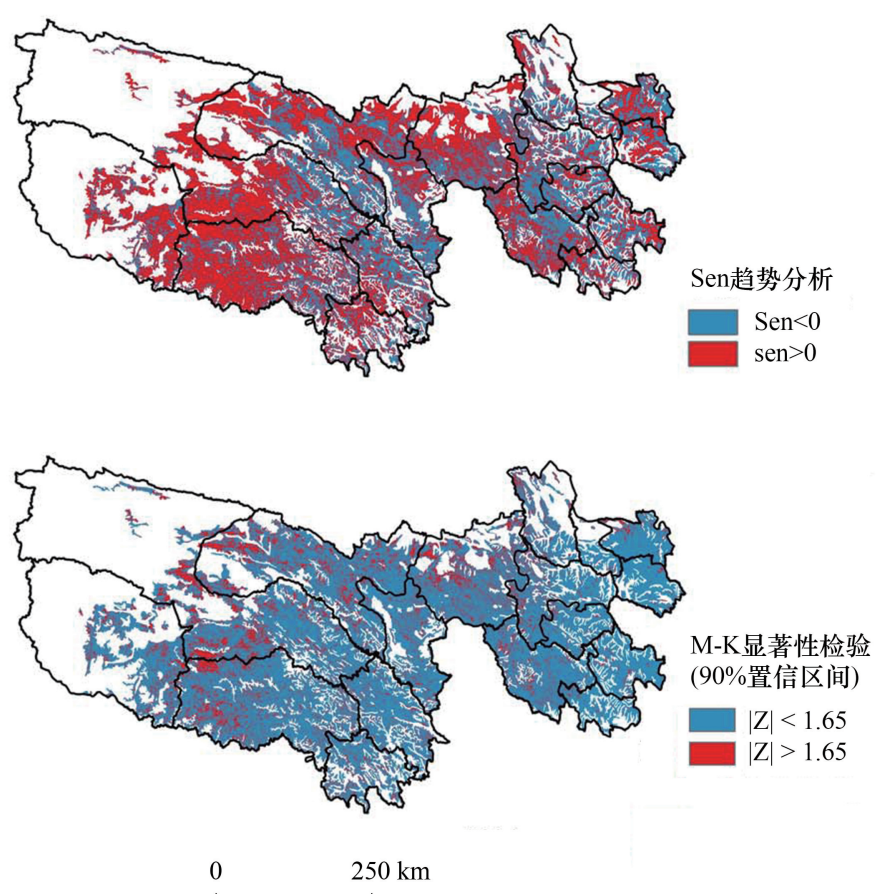

阿里地区
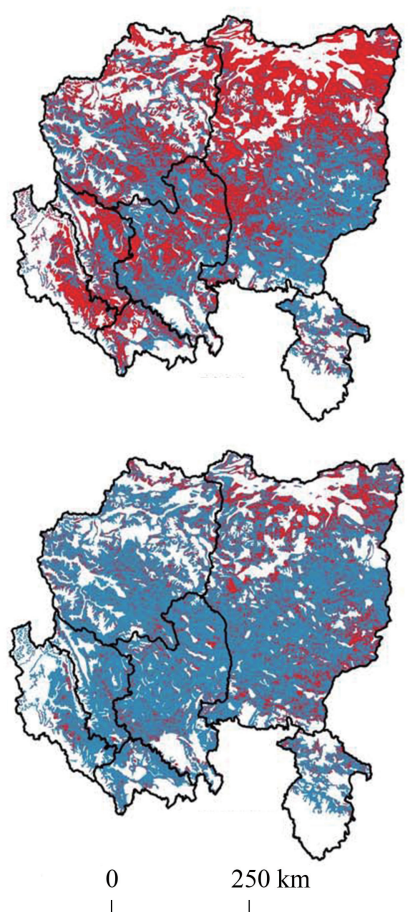

图 7 研究区 NPP 年际变化 Sen+M-K 趋势检验结果

Fig.7 M-K trend test results of interannual changes in NPP in the study area

Sen $>0,|Z|>1.65$ 表示 NPP 序列呈显著上升趋势; Sen $>0,|Z|<1.65$ 表示 NPP 序列呈上升趋势但不显著; Sen $<0,|Z|>1.65$ 表示 NPP 序列呈 显著下降趋势, Sen $<0,|Z|<1.65$, 表示 NPP 序列呈下降趋势但不显著; 以上通过显著性检验均为 $90 \%$ 置信区间

\section{4 放牧与高寒草地植被变化}

放牧等人类活动可能对两种高寒草地植被 NPP 变化产生一定影响。基于三江源和阿里地区各县统计年 鉴( 2000-2016) 中牛羊肉产量代表各县放牧强度, 利用各县域草地 NPP 均值代表植被生长状况, 统计结果表 明两种高寒草地牛羊肉产量年际变化与草地 NPP 变化不存在明显负相关性。在三江源区, 牛羊肉产量呈明 显逐年上升趋势,而高寒草甸植被 NPP 并没有出现逐年下降趋势, 而是出现一定波动变化, 二者线性回归拟 合优度 $R^{2}$ 为 0.0352 , 相关系数 $-0.187(P>0.05)$ 。在阿里地区, 2000-2014 年牛羊肉产量呈现波动上升趋势, 2014-2016 年牛羊肉产量出现下降趋势, 而该地区高寒草原植被 NPP 变化并没有出现相反的变化趋势, 部分 年份 $\left(2014-2016\right.$ 年) 变化趋势与牛羊肉产量变化趋同,二者线性回归拟合优度 $R^{2}$ 为 0.0256 ,相关系数 -0.16 $(P>0.05)$ ( 图 8)。从相关系数符号可以看出, 放牧强度对两种高寒草地植被 NPP 均具有负作用, 但影响均不 明显 $(r<-0.2, P>0.05)$, 不是影响两种高寒草地植被变化的主要因素。

2.5 两种高寒草地 NPP 与气温、降水相关性分析

分别对两种高寒草地 NPP 与气温和降水变化进行相关和偏相关分析, 相关与偏相关系数大小反映温度 与降水对草地植被 NPP 的影响,该方法被广泛用于研究气象因素对植被生长的影响 ${ }^{[36-39]}, 2000-2017$ 年两 种高寒草地 NPP 对气温和降水的响应差异显著,并且偏相关性分析效果明显好于相关性分析 (图 9)。

相关性分析结果表明, 高寒草甸 NPP 与气温呈显著正相关区集中在三江源地区西部格尔木市和杂多县, 整体呈正相关区占比 $48.14 \%$, 而在东南部班玛县、久治县和甘德县则呈现负相关。高寒草原 NPP 与气温呈 显著正相关区集中在阿里地区东北部即改则县北部 (图 9)。气温对两种草地 NPP 的影响存在空间差异, 在 高寒草甸区气温越低其与 NPP 正相关系数越大, 而在高寒草原区气温相对较高地区其与 NPP 正相关系数越 

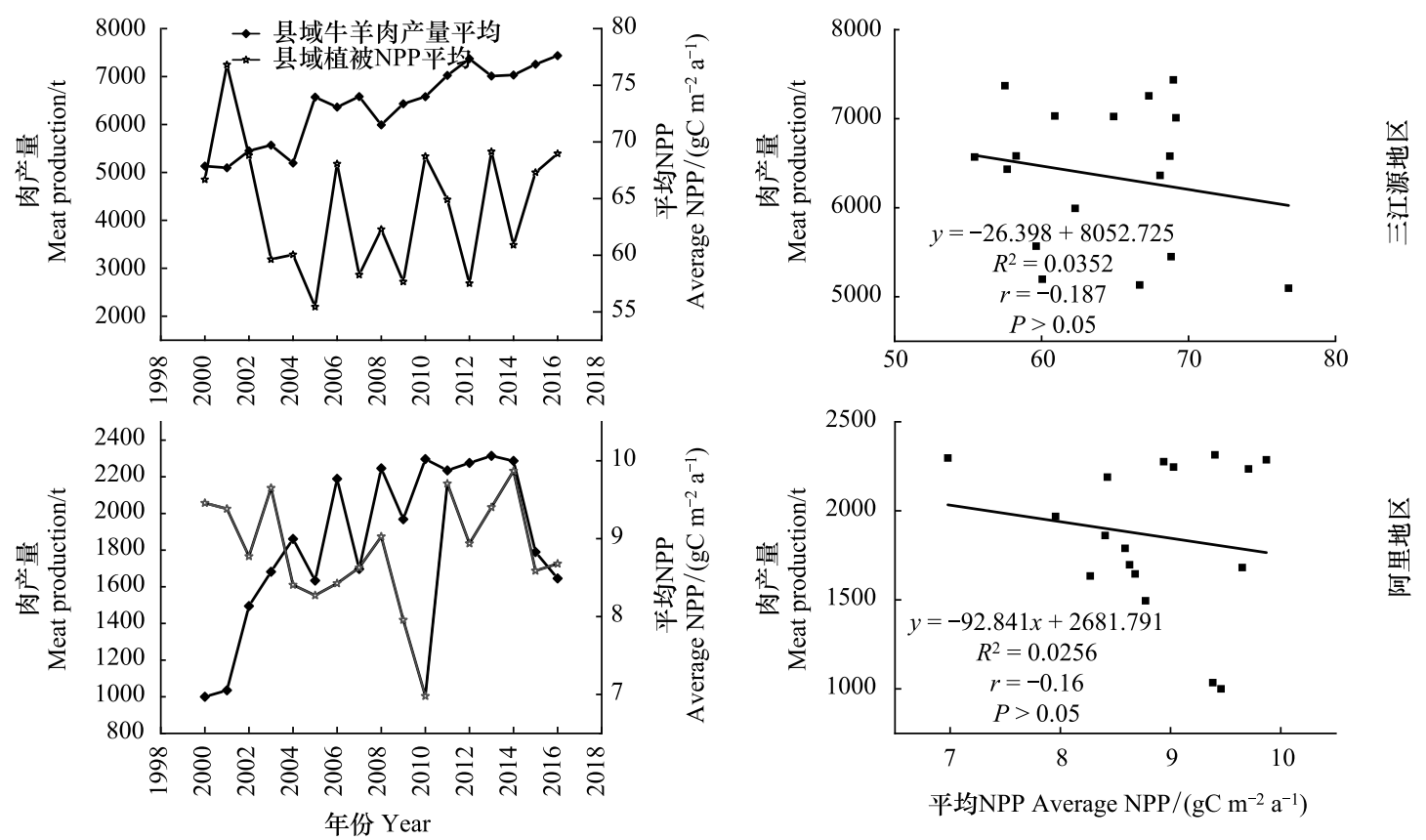

图 8 两种高寒草地牛羊肉产量与植被 NPP 变化

Fig.8 Changes of beef and mutton yield and vegetation NPP in two alpine grasslands

大。NPP 与降水相关性分析表明, 高寒草原区 NPP 与降水呈正相关性面积占比 $49.01 \%$, 而高寒草甸区 NPP 与降水呈正相关面积占比 $20.37 \%$ 。

偏相关性分析结果表明,在控制降水不变,高寒草甸 NPP 与气温呈显著正相关,面积占比达 $64.9 \%$,比相 关性分析 48.14\% 提高 16.76\% (表 3 和表 2)。偏相关性分析对控制降水研究温度对高寒草地 NPP 的影响更 敏感, 尤其在三江源地区东南部甘德县、达日县、久治县及其周边县, 气温与高寒草甸 NPP 呈显著正相关。相 比之下, 阿里地区改则县北部、札达县和革吉县中部部分地区气温与草地 NPP 呈显著正相关,占比达 $49.91 \%$ (表 2)。同样,控制气温不变对降水与草地植被 NPP 进行偏相关性分析, 结果表明在三江源大部分区域,降 水与高寒草甸植被 NPP 不呈显著正相关, 相反在东部及中部大部分县均呈负相关性,占比达 $77.92 \%$ (表 3); 而在西南部格尔木市及杂多县西北部降水相对较少地区呈正相关, 总体呈正相关性面积占比 $22.89 \%$ (表 3)。 阿里地区降水与草地植被 NPP 偏相关分析表明札达县、革吉县中部呈显著正相关性, 改则县西北部降水与草 地 NPP 呈正相关性,总体呈正相关性面积占比 47.76\% (表 3)。

表 2 两种高寒草地 NPP 与气温相关性统计

Table 2 Correlation statistics between net primary productivity (NPP) and temperature of two typical grasslands

\begin{tabular}{lcccc}
\hline $\begin{array}{l}\text { 草地类型 } \\
\text { Grass type }\end{array}$ & $\begin{array}{c}\text { 相关系数 } \\
\text { Correlation coefficient }\end{array}$ & $\begin{array}{c}\text { 面积百分比 } / \% \\
\text { Area percentage }\end{array}$ & $\begin{array}{c}\text { 偏相关系数 } \\
\text { Partial correlation } \\
\text { coefficient }\end{array}$ & $\begin{array}{c}\text { 面积百分比 } / \% \\
\text { Area percentage }\end{array}$ \\
\hline 高寒草甸(三江源地区) & $0<r<0.3$ & 33.51 & $0<r<0.3$ & 42.23 \\
Alpine meadow (TRHR) & $0.3<r<1$ & 14.63 & $0.3<r<1$ & 22.67 \\
& $-0.3<r<0$ & 40.18 & $-0.3<r<0$ & 28.15 \\
高寒草原(阿里地区) & $-1<r<-0.3$ & 11.68 & $-1<r<-0.3$ & 6.95 \\
Alpine steppe (Ali area) & $0<r<0.3$ & 34.32 & $0<r<0.3$ & 35.68 \\
& $0.3<r<1$ & 13.86 & $0.3<r<1$ & 14.23 \\
& $-0.3<r<0$ & 37.56 & $-0.3<r<0$ & 36.28 \\
\hline
\end{tabular}

TRHR: the Three-River Headwaters Region 
阿里地区
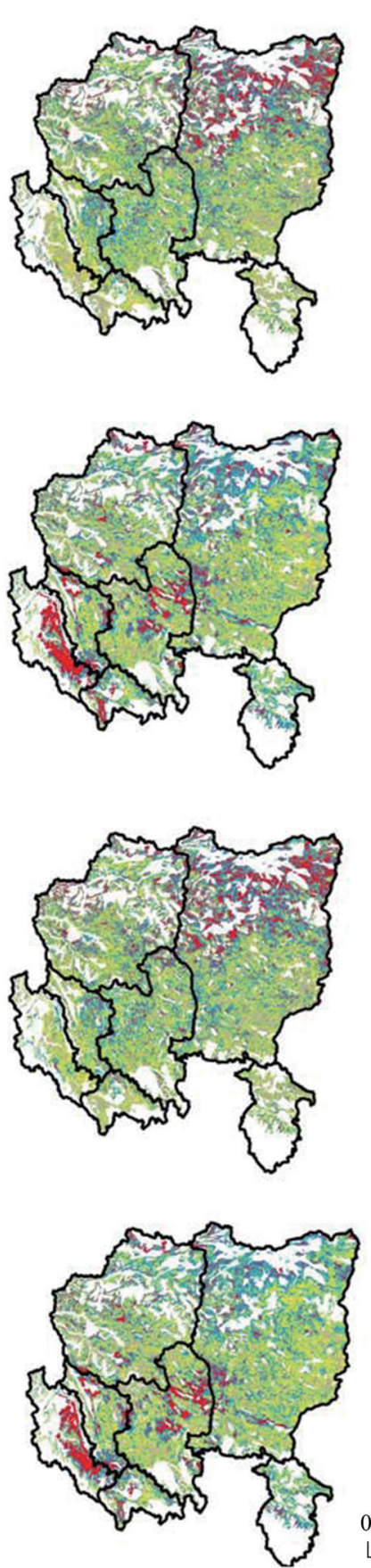

相关性/偏相关性值

$\square-0.9-0.3$
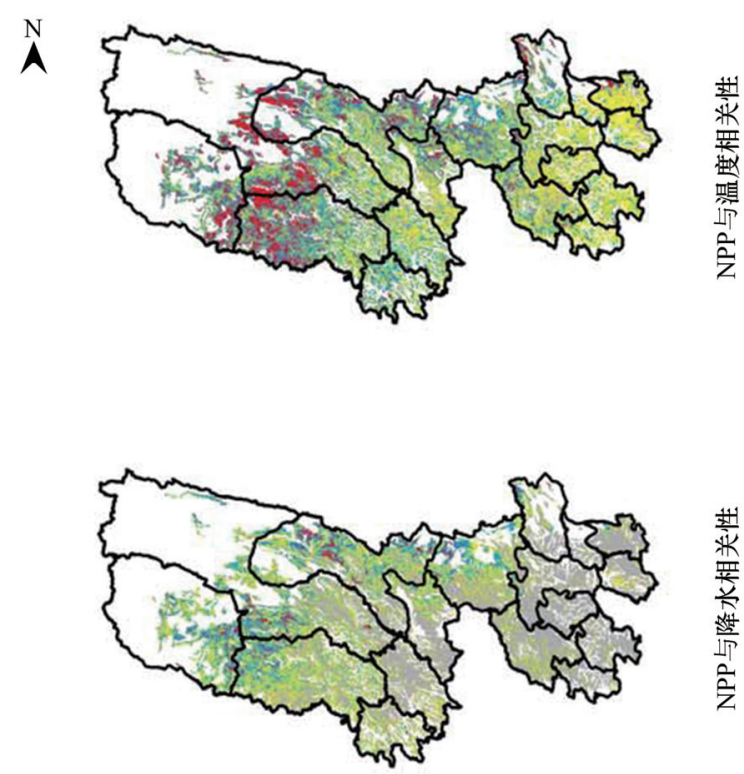

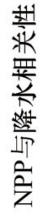

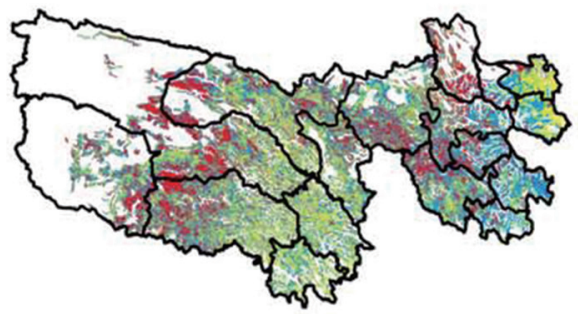

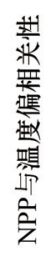

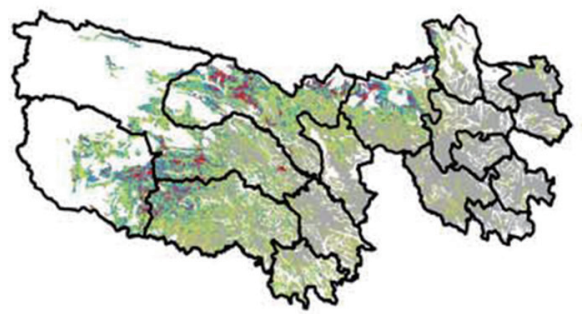

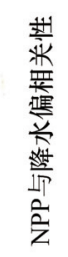

$500 \mathrm{~km}$

需

图 9 研究区 2000-2017 年两种高寒草地 NPP 与气温、降水相关性分析

Fig.9 Correlation analysis of NPP, temperature and precipitation of two typical grasslands in the study area from 2000 to 2017

3 讨论

3.1 两种高寒草地气温、降水变化差异分析

三江源与阿里地区所处纬度相当,且均处于暖湿化趋势, 二者年平均气温分别以 $0.085^{\circ} \mathrm{C} / \mathrm{a}$ 和 $0.084^{\circ} \mathrm{C} / \mathrm{a}$ 
的速率上升,相比张镱锂等人 ${ }^{[8]}$ 计算青藏高原 1980-2010 年平均每年上升 $0.06^{\circ} \mathrm{C}$ 略高; 而年平均降水量分别 以平均每年 $3.87 \mathrm{~mm}$ 和 $2.23 \mathrm{~mm}$ 速率增加, 相比陆晴等 ${ }^{[40]}$ 计算整个青藏高原 $1982-2013$ 年平均每年降水增 加 $0.96 \mathrm{~mm}$ 高, 这表明 2000-2017 年阿里与三江源地区暖湿化速率高于青藏高原平均水平。两地升温速率 相当,但三江源高寒草甸区增湿速率明显较阿里高寒草地区快, 可能原因是 2000-2017 年三江源高寒草甸区 同时受中纬度西风带和南亚季风共同影响增强, 导致降水增加相对较多 ${ }^{[41]}$ 。

表 3 两种高寒草地 NPP 与降水相关性统计

Table 3 Statistics of the correlation between NPP and precipitation in two typical grasslands

\begin{tabular}{lcccc}
\hline $\begin{array}{l}\text { 草地类型 } \\
\text { Grass type }\end{array}$ & $\begin{array}{c}\text { 相关系数 } \\
\text { Correlation coefficient }\end{array}$ & $\begin{array}{c}\text { 面积百分比 } / \% \\
\text { Area percentage }\end{array}$ & $\begin{array}{c}\text { 偏相关系数 } \\
\text { Partial correlation } \\
\text { coefficient }\end{array}$ & $\begin{array}{c}\text { 面积百分比 } / \% \\
\text { Area percentage }\end{array}$ \\
\hline 高寒草甸(三江源地区) & $0<r<0.3$ & 17.22 & $0<r<0.3$ & 17.76 \\
Alpine meadow (TRHR) & $0.3<r<1$ & 3.15 & $0.3<r<1$ & 5.13 \\
& $-0.3<r<0$ & 30.14 & $-0.3<r<0$ & 26.02 \\
高寒草原(阿里地区) & $-1<r<-0.3$ & 49.49 & $-1<r<-0.3$ & 51.09 \\
Alpine steppe (Ali area) & $0<r<0.3$ & 35.98 & $0<r<0.3$ & 35.83 \\
& $0.3<r<1$ & 13.03 & $0.3<r<1$ & 11.93 \\
& $-0.3<r<0$ & 37.12 & $-0.3<r<0$ & 38 \\
\hline
\end{tabular}

3.2 两种高寒草地放牧等人类活动与植被变化

研究中采用两种高寒草地牛羊肉产量表示放牧情况,一定程度反映当地放牧活动强弱。根据结果分析, 三江源区放牧强度比阿里地区强, 且三江源区东部人类活动相对密集, 放牧等人类活动比阿里地区强度更大, 但两地高寒草地植被 NPP 变化主要受气候变化影响,放牧活动影响较小。这与一些学者研究结果相近, 三江 源区位于气候变化主导作用区 ${ }^{[23,42]}$ 。在三江源区同时有一系列生态保护工程, 对高寒草甸植被 NPP 具有一 定影响,主要集中在三江源国家公园区域内,彭凯峰等人 ${ }^{[17]}$ 对该区域内人类活动和气候变化对植被变化影响 进行对比研究, 发现降水和温度预测的植被覆盖度与观测到的植被覆盖度变化趋势基本吻合, 表明三江源国 家公园生态保护区植被变化主要受气候变化影响, 人类活动影响较小。两种高寒草地植被 NPP 变化受放牧 等人类活动影响较小,受气候变化影响较大。

3.3 两种高寒草地植被 NPP 变化与气候变化相关性差异分析

通过相关与偏相关分析得出气温是促进高寒草甸植被生长主要因素, 而降水对大部分高寒草甸植被 NPP 促进作用不明显,甚至在降水相对丰沛地区出现显著负相关, 该研究结果与周秉荣等 ${ }^{[22]}$ 、王军邦等 ${ }^{[43]}$ 、 朱文会等 ${ }^{[4]}$ 和 Xiong 等 ${ }^{[45]}$ 研究得到气温是影响三江源区植被 NPP 增加的关键气象因子结论相似。Bai 等 ${ }^{[42]}$ 研究直接得出气候变暖有助于三江源高寒植被增长, 与本研究结果一致。本研究结果中降水相对丰沛 区降水与高寒草甸植被 NPP 呈显著负相关, 可能原因是高寒草甸在满足一定降水量后降水的增加意味着日 照时数的减小, 因此太阳有效辐射的减少, 造成气温的下降, 而气温是高寒草甸植被生长的主要促进因素, 降 水增多一定程度上会对高寒草甸植被生长产生负作用。以上温度和降水对高寒草地植被的影响在阿里高寒 草原区却没有得到相似的结果, 温度并不是高寒草原植被 NPP 增长关键因子, 相反温度和降水对高寒草原植 被 NPP 增长的影响相当 (呈正相关占比均为 $49 \%$ 左右)。一方面可能是阿里地区温度相对更高, 不像三江源 大部分地区温度成为植被生长关键限制因素; 另一方面阿里地区降水相对匮乏, 植被生长受到降水不足的胁 迫, 不能与相对充足的温度协调促进植被生理生态过程。因此在三江源地区高寒草甸恢复与保护应该更加注 重对耐低温植物培育与保护,在阿里高寒草原区应该对耐低温耐旱植物培育与保护。

本文研究了三江源高寒草甸与阿里高寒草原植被 NPP 变化及其气象驱动因子差异, 为青藏高原气候变 化与不同草地响应研究提供参考资料。同时本研究也存在一些不足, 以气温和降水表征气候影响因素, 认为 
太阳辐射差异较小, 未考虑太阳辐射差异对植被生长影响; 在分析放牧强度对高寒草地植被的影响中未能将 县域尺度产肉量分解到栅格尺度与植被 NPP 对比研究,存在一定不确定性; 对于三江源与阿里地区不同生态 保护工程实施对两种高寒草地 NPP 产生的影响缺乏研究。接下来的研究应该更深人考虑气候变化、生态保 护工程共同对两种高寒草地 NPP 变化的影响。

\section{4 结论}

本研究主要结论如下:

(1) 三江源高寒草甸与阿里高寒草原区均处于暖湿化趋势, 且三江源地区增湿速率较阿里地区快。(2) 三江源高寒草甸和阿里高寒草原植被 NPP 均呈现东南向西北递减空间格局; 三江源及阿里地区高寒草地 NPP 增长显著区均位于降水和温度相对低值区域,且高寒草甸植被 NPP 增长趋势总体较高寒草原区明显。 (3) 两种高寒草地植被变化受放牧影响不大, 受气候变化影响较大。(4) 两种高寒草地植被 NPP 增长的气象 驱动因子差异明显, 气温升高是促进高寒草甸植被 NPP 增长关键因子, 降水增多对三江源东北部高寒草甸植 被增长具有一定抑制作用; 而对于高寒草原植被,气温和降水增加共同促进高寒草原植被 NPP 增长。

致谢:NPP 数据来源于“国家青藏高原科学数据中心” (http://data.tpdc.ac.cn)

\section{参考文献 ( References) :}

[ 1 ] 岳广阳, 赵林, 赵拥华, 李元寿. 青藏高原草地生态系统碳通量研究进展. 冰川冻土, 2010, 32(1) : 166- 174.

[ 2 ] 丁明军, 张镱锂, 刘林山, 王兆锋. 1982-2009 年青藏高原草地覆盖度时空变化特征. 自然资源学报, 2010, 25(12): 2114-2122.

[ 3 ] 孙鸿烈, 郑度, 姚檀栋, 张镱锂. 青藏高原国家生态安全屏障保护与建设. 地理学报, 2012, 67(1): 3-12.

[ 4 ] 林振耀, 吴祥定. 青藏高原气候区划. 地理学报, 1981, 36(1): 22-32.

[ 5 ] 徐嘉听, 房世波, 张廷斌, 朱永超, 吴东, 易桂花. 2000-2016 年三江源区植被生长季 NDVI 变化及其对气候因子的响应. 国土资源遥 感, 2020, 32(1): 237-246.

[ 6 ] 杨潇, 郭兵, 韩保民, 陈舒婷, 杨飞, 范业稳, 何田莉, 刘悦. 青藏高原 NPP 时空演变格局及其驱动机制分析. 长江流域资源与环境, $2019,28(12): 3038-3050$.

[ 7 ] 王志鹏, 张宪洲, 何永涛, 李猛, 石培礼, 沮佳星, 牛荤. 2000-2015 年青藏高原草地归一化植被指数对降水变化的响应. 应用生态学 报, 2018, 29(1): 75-83.

[ 8 ] 杨元合, 朴世龙. 青藏高原草地植被覆盖变化及其与气候因子的关系. 植物生态学报, 2006, 30(1): 1-8.

[ 9 ] 孟凡栋, 汪诗平, 白玲. 青藏高原气候变化与高寒草地. 广西植物, 2014, 34(2): 269-275, 262-262.

[10] 刘晓东, 张敏锋, 惠晓英, 康兴成. 青藏高原当代气候变化特征及其对温室效应的响应. 地理科学, 1998, 18(2): 113-121.

[11］徐丽娇, 胡泽勇, 赵亚楠, 洪潚宇. 1961-2010 年青藏高原气候变化特征分析. 高原气象, 2019, 38(5): 911-919.

[12] 周伟, 刚成诚, 李建龙, 章超斌, 穆少杰, 孙政国. 1982-2010 年中国草地覆盖度的时空动态及其对气候变化的响应. 地理学报, 2014, $69(1): 15-30$.

[13] 刘风, 曾永年. 近 16 年青海高原植被 NPP 时空格局变化及气候与人为因素的影响. 生态学报, 2019, 39(5): 1528-1540.

[14] 薛晓玉, 王晓云, 段含明, 颕耀文. 北方农牧交错带植被 NPP 的时空变化及其驱动因子分析.水土保持研究, 2021, 28(2)：190-197.

[15] Gao Y H, Zhou X, Wang Q, Wang C Z, Zhan Z M, Chen L F, Yan J X, Qu R. Vegetation net primary productivity and its response to climate change during 2001-2008 in the Tibetan Plateau. Science of the Total Environment, 2013, 444: 356-362.

[16] 何楷迪, 孙建, 陈秋计. 气候要素和土壤质地对青藏高原草地净初级生产力和降水利用率的影响. 草业科学, 2019, 36(4): 1053-1065.

[17］彭凯锋, 蒋卫国, 侯鹏, 孙晨犧, 赵祥, 肖如林. 三江源国家公园植被时空变化及其影响因子. 生态学杂志, 2020, 39(10): 3388-3396.

[18] Chen S T, Guo B, Zhang R, Zang W Q, Wei C X, Wu H W, Yang X, Zhen X Y, Li X, Zhang D F, Han B M, Zhang H L. Quantitatively determine the dominant driving factors of the spatial一temporal changes of vegetation NPP in the Hengduan Mountain area during $2000-2015$. Journal of Mountain Science, 2021, 18(2): 427-445.

[19] Zhang Y L, Qi W, Zhou C P, Ding M J, Liu L S, Gao J G, Bai W Q, Wang Z F, Zheng D. Spatial and temporal variability in the net primary production of alpine grassland on the Tibetan Plateau since 1982. Journal of Geographical Sciences, 2014, 24(2) : 269- 287.

[20] Zheng Z T, Zhu W Q, Zhang Y J. Seasonally and spatially varied controls of climatic factors on net primary productivity in alpine grasslands on the Tibetan Plateau. Global Ecology and Conservation, 2020, 21: e00814. 
[21] 韩炳宏, 周秉荣, 颜玉倩, 石明明, 苏淑兰, 赵恒和, 牛得草, 傅华. 2000-2018 年间青藏高原植被覆盖变化及其与气候因素的关系分析. 草地学报, 2019, 27(6): 1651-1658.

[22] 周秉荣, 朱生翠, 李红梅. 三江源区植被净初级生产力时空特征及对气候变化的响应. 干旱气象, 2016, 34(6) : 958-965, 988-988.

[23] 陈舒婷, 郭兵, 杨飞, 韩保民, 范业稳, 杨潇, 何田莉, 刘悦, 杨雯娜. 2000-2015 年青藏高原植被 NPP 时空变化格局及其对气候变化的 响应. 自然资源学报, 2020,35(10): 2511-2527.

[24] 戴黎聪, 郭小伟, 张法伟, 柯浔, 曹莹芳, 李以康, 李茜, 林丽, 朋措吉, 舒锴, 曹广民, 杜岩功. 青藏高原两种植被类型净初级生产力与 气候因素的关系及周转值分析. 生态学报, 2019, 39(14): 5241-5251.

[25] Gao Q Z, Guo Y Q, Xu H M, Ganjurjav H, Li Y, Wan Y F, Qin X B, Ma X, Liu S. Climate change and its impacts on vegetation distribution and net primary productivity of the alpine ecosystem in the Qinghai-Tibetan Plateau. Science of the Total Environment, 2016, 554-555: 34-41.

[26] 牛牟, 张立峰, 马荣荣, 刘晓琴, 张翔, 赵亮, 古松. 高寒草甸土壤微生物量及酶活性的研究. 南开大学学报: 自然科学版, 2016, 49 (4) : 53-60.

[27] 裴志永, 周才平, 欧阳华, 杨文斌. 青藏高原高寒草原区域碳估测. 地理研究, 2010, 29(1): 102-110.

[28] 冯晓玛, 黄斌斌, 李若男, 郑华. 三江源区生态系统和土壤保持服务对未来气候变化的响应特征. 生态学报, 2020, 40(18)：6351-6361.

[29] 边多, 普布次仁, 尼珍, 刘奎军. 基于 MODIS-NDVI 时序数据的西藏阿里地区草地覆盖时空变化. 中国草地学报, 2014, 36(3)：73-78.

[30］赵旺林, 罗天祥, 张林. 气候变化与放牧对西藏典型高寒荒漠草地植被指数变化的相对影响. 生态学报, 2019, 39(22): 8494-8503.

[31］刘文俊. 青藏高原生态资产评估遥感反演净初级生产力数据集. 国家青藏高原科学数据中心, 2019, doi : 10.11888/Ecolo.tpdc.270532.

[32] 吴炳方, 苑全治, 颜长珍, 王宗明, 于信芳, 李爱农, 马荣华, 黄进良, 陈劲松, 常存, 刘成林, 张否, 李晓松, 曾源, 包安明. 21 世纪前 十年的中国土地覆盖变化. 第四纪研究, 2014, 34(4) : 723-731.

[33 ] Liang T G, Yang S X, Feng Q S, Liu B K, Zhang R P, Huang X D, Xie H J. Multi-factor modeling of above-ground biomass in alpine grassland: a case study in the Three-River Headwaters Region, China. Remote Sensing of Environment, 2016, 186: 164-172.

[34] 王佃来, 刘文萍, 黄心洣. 基于 Sen+Mann-Kendall 的北京植被变化趋势分析. 计算机工程与应用, 2013, 49(5): 13- 17.

[35] 胡刚, 宋慧. 基于 Mann-Kendall 的济南市气温变化趋势及突变分析. 济南大学学报: 自然科学版, 2012, 26(1) : 96-101.

[36] 许洁, 陈惠玲, 商沙沙, 杨欢, 朱高峰, 刘晓文. 2000-2014 年青藏高原植被净初级生产力时空变化及对气候变化的响应. 干旱区地理, 2020, 43(3): 592-601.

[37] 王晓峰, 程昌武, 尹礼唱, 冯晓明, 卫新东. 新疆生态系统服务时空变化及权衡协同关系. 生态学杂志, 2020, 39(3) : 990-1000.

[38] 刘刚, 孙睿, 肖志强, 崔天翔. 2001-2014 年中国植被净初级生产力时空变化及其与气象因素的关系. 生态学报, 2017, 37 (15)： 4936-4945.

[39] 朱玉果, 杜灵通, 谢应忠, 刘可, 宫菲, 丹杨, 王乐, 郑琪琪. 2000-2015 年宁夏草地净初级生产力时空特征及其气候响应. 生态学报, 2019, 39(2) : 518-529.

[40］陆晴, 吴绍洪, 赵东升. 1982-2013 年青藏高原高寒草地覆盖变化及与气候之间的关系. 地理科学, 2017, 37(2) : 292-300.

[41] 张宇, 李铁键, 李家叶, 钟德钔. 西风带和南亚季风对三江源雨季水汽输送及降水的影响. 水科学进展, 2019, 30(3): 348-358.

[42] Bai Y F, Guo C C, Degen A A, Ahmad A A, Wang W Y, Zhang T, Li W Y, Ma L, Huang M, Zeng H J, Qi L Y, Long R J, Shang Z H. Climate warming benefits alpine vegetation growth in Three-River Headwater Region, China. Science of the Total Environment, 2020, $742: 140574$.

[43] 王军邦, 刘纪远, 邵全琴, 刘荣高, 㷊江文, 陈卓奇. 基于遥感——过程耦合模型的 1988-2004 年青海三江源区净初级生产力模拟. 植 物生态学报, 2009, 33(2): 254-269.

[44] 朱文会, 毛飞, 徐影, 郑军, 宋立雪. 三江源区植被指数对气候变化的响应及预测分析. 高原气象, 2019, 38(4) : 693-704.

[45] Xiong Q L, Xiao Y, Halmy M W A, Dakhil M A, Liang P H, Liu C G, Zhang L, Pandey B, Pan K W, El Kafraway S B, Chen J. Monitoring the impact of climate change and human activities on grassland vegetation dynamics in the northeastern Qinghai-Tibet Plateau of China during 20002015. Journal of Arid Land, 2019, 11(5): 637-651. 